\title{
KARAKTERISTIK TEKSTUR ROTI MANIS DARI TEPUNG, PATI, SERAT DAN PIGMEN ANTOSIANIN UBI JALAR UNGU
}

\section{Characterization Texture of Sweet Bread from Flour, Starch, Fiber and Anthocyanin Pigment of Purple Sweet Potatoes}

\author{
Jasmine Aldrina Iswara $^{1 *}$, Elisa Julianti ${ }^{1,2}$, Mimi Nurminah ${ }^{1,2}$
}

1) Program Studi Ilmu dan Teknologi Pangan FP Universitas Sumatera Utara Medan Jl. Prof. A. Sofyan No. 3 Kampus USU Medan 20155

2) Pusat Studi Umbi dan Tanaman Akar FP Universitas Sumatera Utara Medan

JI. Prof. A. Sofyan No. 3 Kampus USU Medan 20155

*Penulis Korespondensi: Email: jasminealdrinaiswara@ymail.com

\begin{abstract}
ABSTRAK
Tujuan pelaksanaan dari penelitian ini untuk mengetahui pengaruh tepung, pati, serat, dan pigmen antosianin ubi jalar ungu terhadap karakteristik tekstur roti manis. Pada penelitian ini rancangan yang digunakan yaitu rancangan acak lengkap non faktorial terdiri dari 2 kontrol dan 6 perlakuan perbandingan tepung: pati: serat: pigmen antosianin ubi jalar ungu. Hasil analisis terhadap karakteristik tekstur roti manis menunjukkan perbandingan antara tepung, pati, serat, serta pigmen antosianin ubi jalar ungu berpengaruh berbeda yang nyata atau $P$ lebih kecil dari 0.05 untuk tekstur (cohesiveness) serta berbeda yang sangat nyata atau P lebih kecil dari 0.01 untuk tekstur (chewiness, adhesiveness, \% deformasi, hardness, gumminess, dan springiness). Penambahan pati ubi jalar ungu dengan jumlah semakin meningkat pada roti manis dapat meningkatkan cohesiveness, adhesiveness, springiness, dan gumminess serta menurunkan \% deformasi sedangkan penambahan serat ubi jalar ungu dengan jumlah semakin meningkat pada roti manis dapat meningkatkan chewiness, hardness, dan gumminess.
\end{abstract}

Kata kunci: Pati ubi jalar ungu, Pigmen antosianin ubi jalar ungu, Roti manis, Serat ubi jalar ungu, Tepung ubi jalar ungu

\begin{abstract}
The aim of this research was to determine the effect of flour, starch, fiber, and anthocyanin pigment of purple sweet potatoes on characterization texture of sweet bread. On this research was conducted using non factorial completely randomized design with one factor of 2 controls and 6 treatment of flour comparison : starch : fiber : anthocyanin pigment of purple sweet potatoes. The results of the analysis of the characterization texture of sweet bread showed that the comparison of flour, starch, fiber, and anthocyanin pigment of purple sweet potatoes had significant effect or $P$ is smaller than 0.05 on the texture (cohesiveness) and high significant effect or $P$ is smaller than 0.01 on texture (chewiness, adhesiveness, \% deformation, hardness, gumminess, and springiness). Adding more starch purple sweet potatoes to sweet bread can increase cohesiveness, adhesiveness, springiness, and gumminess and decrease \%deformation. While the addition of purple sweet potato fiber which is more and more on sweet bread can increase chewiness, hardness, and gumminess.
\end{abstract}

Keywords: Purple sweet potato starch, purple sweet potato anthocyanin pigment, sweet bread, purple sweet potato fiber, purple sweet potato flour 


\section{PENDAHULUAN}

Pada dasarnya roti dibagi menjadi dua jenis, roti tawar dan juga roti manis. Roti manis adalah roti dengan citarasa yang manis serta teksturnya yang lebih empuk. Selain dari segi rasa, roti manis juga memiliki bentuk yang menarik karena dibuat dari adonan yang dibentuk-bentuk sesuai dengan keinginan (Barlina, 2013). Roti manis terbuat dari adonan yang menggunakan banyak gula, lemak, dan telur (Andragogi dkk., 2018). Tepung terigu digunakan sebagai bahan utama untuk membuat roti manis. Pembuatan roti manis dibuat dengan cara memfermentasi tepung terigu menggunakan ragi instan (Saccharomyces cerevisiae) (Halim dkk., 2015).

Tepung terigu mempunyai sifat kimia yang hamper mirip dengan tepung ubi jalar ungu seperti kadar abu, serat, kalori sehingga dapat digunakan untuk menggantikan tepung terigu (Fatmala dan Adi, 2017). Jika dibandingkan dengan tepung terigu, tepung ubi jalar ungu memiliki kadar abu dan serat yang lebih tinggi serta kalori dan karbohidratnya yang hampir setara dengan tepung terigu. Penggunaan tepung ubi jalar ungu untuk alternatif sebagai sumber karbohidrat dan juga dapat disubstitusikan pada produk-produk dari terigu serta turunannya sehingga dapat memberikan nilai tambah terutama untuk kesehatan (Hardoko dkk., 2010). Penggunaan tepung ubi jalar ungu juga lebih luwes karena dapat dipakai untuk bahan utama atau bahan campuran dengan terigu untuk membuat beberapa jenis makanan, diantaranya mie, kue kering, roti, dan kue basah (Santosa dkk., 2016).

Ubi jalar dapat menjadi alternatif sumber karbohidrat karena kandungan amilosa ubi jalar berkisar antara 20\%-33\%. Kebanyakan varietas ubi jalar mempunyai kandungan pati di bawah 30\%. Ukuran, bentuk granula, struktur, perbandingan massa amilopektin dan tingkatan crystallinity mempengaruhi sifat fungsional pati. Karakteristik pati pada bahan makanan akan mempengaruhi sifat fungsional pati seperti swelling, gelatinization, pasting properties, retrogradasi, digestibility, dan suitability untuk proses (Waramboi dkk., 2011).

Serat pangan atau dietary fiber termasuk polisakarida dengan sifat tidak dapat dihidrolisis ataupun dicerna oleh enzim pencernaan pada manusia (Silalahi, 2006). Kadar serat pangan ubi jalar ungu tergolong tinggi yaitu 2.30 sampai $3.90 \mathrm{~g} / 100 \mathrm{~g}$ bb sedangkan ubi jalar putih atau kuning yaitu 2.30 sampai $3.30 \mathrm{~g} / 100 \mathrm{~g}$ bb. Asurapan serat pangan yang dianjurkan yaitu $25 \mathrm{~g}$ per hari. Konsumsi sebanyak $100 \mathrm{~g}$ ubi jalar dapat mencukupi angka kecukupan asupan sebanyak $8 \%$ (Woolfe, 1999).

Ubi jalar ungu memiliki keunggulan yang lain berupa antosianin yang ada di dalamnya adalah suatu senyawa antioksidan. Antosianin dapat digolongkan pada kelompok flavonoid. Flavonoid merupakan senyawa dengan penyebaran yang luas diantara spesies tanaman. Flavonoid merupakan pigmen yang memiliki warna biru, merah, serta ungu. Pada ubi jalar ungu terkandung antosianin berkisar $\pm 519 \mathrm{mg}$ per $100 \mathrm{~g} \mathrm{bb}$ (Sigit, dkk., 2005). Antosianin di dalam makanan memberikan keuntungan sebagai antikanker, melindungi hati, dan mengurangi serangan jantung. Selain itu, warna merah-ungu yang mendalam dari warna antosianin membuat pigmen ini semakin menarik sebagai sumber pewarna alami untuk makanan atau industri tekstil sebagai alternatif untuk sintesis pewarna makanan (Wegener dkk., 2009).

Suatu bentuk inovasi sebagai upaya untuk pemanfaatan ubi jalar ungu yaitu dengan menjadikan roti manis yang terbuat dari tepung, pati, serat, dan pigmen antosianin ubi jalar ungu. Roti manis dipilih dalam penelitian ini karena konsumsi roti di Indonesia saat ini cukup tinggi. Selain itu, penelitian terhadap penggunaan tepung dan pati dari ubi terutama ubi jalar yang berwarna ungu untuk mengurangi jumlah impor gandum serta meningkatkan nilai fungsional dari ubi jalar. Pemanfaatan serat dan pigmen antosianin ubi jalar ungu juga dilakukan karena mengingat biasanya dalam pembuatan pati ubi jalar ungu, serat dan pigmen antosianin dibuang begitu saja. Serat dan pigmen antosianin tersebut sebenarnya masih memiliki nilai fungsional sehingga perlu dilakukan penggunaan lanjutan agar lebih bermanfaat. Berdasarkan penelitian sebelumnya yaitu Chuango (2018), telah dilakukan penelitian terhadap mutu cakes dari tepung ubi jalar ungu dengan pengaruh pre-treatment sehingga perlu dilakukannya penelitian lanjutan terkait dengan perbandingan tepung, pati, 
serat, dan pigmen antosianin ubi jalar ungu terhadap mutu bakery lain seperti roti manis. Tujuan pelaksanaan dari penelitian ini untuk mengetahui karakteristik tekstur roti manis dari tepung, pati, serat, dan pigmen antosianin ubi jalar ungu.

\section{BAHAN DAN METODE}

Bahan dan metode dari pelaksanaan penelitian ini terdiri dari bahan, alat, desain penelitian, tahapan penelitian, metode penelitian, dan prosedur analisis.

\section{Bahan}

Bahan-bahan yang digunakan dalam pelaksanaan penelitian diantaranya tepung, pati, serat, dan pigmen antosianin ubi jalar ungu yang dibuat sendiri serta bahan-bahan untuk pembuatan roti manis seperti tepung terigu merk Cakra kembar bogasari, gula merk Gulaku, susu cair full cream merk Ultra Milk, bread improver merk Bakerin Plus, shortening merk Bake Master, ragi instan merk Saf-Instant, garam merk Dolphin, xanthan gum merk Meihua, telur, dan margarin merk Blue Band.

\section{Alat}

Alat-alat yang digunakan dalam pembuatan roti manis yaitu timbangan merk Camry, loyang merk Hock, mixer merk Cosmos, dan oven pemanggang merk Mega Lux. Alat yang digunakan untuk pengujian tekstur roti manis yaitu texture analyzer merk Brookfield.

\section{Desain Penelitian}

Penelitian ini terdiri dari 2 kontrol (kontrol 1 adalah roti dari $100 \mathrm{~g}$ ubi jalar ungu, dan kontrol 2 roti dari $100 \mathrm{~g}$ tepung terigu), dan 6 perlakuan perbandingan tepung : pati : serat : pigmen antosianin ubi jalar ungu $(\mathrm{g})$ yaitu :

$\mathrm{P}_{1}=100 \mathrm{~g}$ tepung ubi jalar ungu (kontrol 1 )

$\mathrm{P}_{2}=73: 25: 0: 2$

$P_{3:}=73: 20: 5: 2$

$P_{4}=73: 15: 10: 2$

$P_{5}=73: 10: 15: 2$

$\mathrm{P}_{6}=73: 5: 20: 2$

$\mathrm{P}_{7}=73: 0: 25: 2$

$\mathrm{P}_{8}=100 \mathrm{~g}$ tepung terigu (kontrol 2)

\section{Tahapan Penelitian}

Pembuatan roti dari campuran tepung, pati, serat, dan pigmen antosianin ubi jalar ungu serta pengamatan karakteristik tekstur roti. Tepung, pati, serat, dan pigmen antosianin ubi jalar ungu dicampur sesuai dengan perlakuan. Bahan-bahan lain disiapkan dan ditimbang seperti pada formulasi. Formulasi roti dari tepung, pati, serat, dan pigmen antosianin ubi jalar ungu dilihat pada Tabel 1.

Bahan-bahan seperti ragi instan, gula, garam, xanthan gum, dan bread impover diaduk dengan menggunakan mixer dengan kecepatan rendah hingga homogen, kemudian ditambahkan telur, pigmen antosianin ubi jalar ungu dan susu cair full cream secara perlahan lalu diaduk dengan mixer hingga membentuk adonan. Shortening ditambahkan sambil tetap diaduk sehingga membentuk adonan yang kalis. Selanjutnya, adonan ditimbang dan dibagi dengan berat masing-masing $50 \mathrm{~g}$ dan dibentuk bulatan. Selanjutnya, adonan disusun di atas loyang yang terlebih dahulu telah diolesi dengan margarin lalu adonan didiamkan kembali selama 30 menit. Adonan roti bersama loyangnya dimasukkan ke oven suhu $165^{\circ} \mathrm{C}$ dengan waktu pemanggangan 25 menit dan dibiarkan hingga dingin pada suhu ruang selama 30 menit, setelah itu dilakukan pengemasan menggunakan plastik polietilen sebelum dianalisis. 
Karakteristik Tekstur Roti Manis - Iswara, dkk Jurnal Pangan dan Agroindustri Vol.7 No.4: 12-21, Oktober 2019

Tabel 1. Formulasi roti dari Tepung, Pati, Serat, dan Pigmen Antosianin Ubi Jalar Ungu (g)

(Modifikasi Hardoko dkk. 2010)

\begin{tabular}{lcccccccc}
\hline Bahan & \multicolumn{7}{c}{ Perlakuan } \\
\cline { 2 - 9 } & $\begin{array}{c}\mathrm{P}_{1} \\
\text { (kontrol 1) }\end{array}$ & $\mathrm{P}_{2}$ & $\mathrm{P}_{3}$ & $\mathrm{P}_{4}$ & $\mathrm{P}_{5}$ & $\mathrm{P}_{6}$ & $\mathrm{P}_{7}$ & $\begin{array}{c}\mathrm{P}_{8} \\
\text { (kontrol 2) }\end{array}$ \\
\hline $\begin{array}{l}\text { Tepung ubi jalar ungu } \\
\text { (g) }\end{array}$ & 100 & 73 & 73 & 73 & 73 & 73 & 73 & 0 \\
Pati ubi jalar ungu (g) & 0 & 25 & 20 & 15 & 10 & 5 & 0 & 0 \\
Serat ubi jalar ungu (g) & 0 & 0 & 5 & 10 & 15 & 20 & 25 & 0 \\
Pigmen antosianin ubi & 0 & 2 & 2 & 2 & 2 & 2 & 2 & 0 \\
jalar ungu (g) & & & & & & & & \\
Tepung terigu (g) & 0 & 0 & 0 & 0 & 0 & 0 & 0 & 100 \\
Gula (g) & 30 & 30 & 30 & 30 & 30 & 30 & 30 & 30 \\
Ragi instan (g) & 2 & 2 & 2 & 2 & 2 & 2 & 2 & 2 \\
Shortening (g) & 10 & 10 & 10 & 10 & 10 & 10 & 10 & 10 \\
Susu cair full cream (L) & 60 & 60 & 60 & 60 & 60 & 60 & 60 & 60 \\
Garam (g) & 1.5 & 1.5 & 1.5 & 1.5 & 1.5 & 1.5 & 1.5 & 1.5 \\
Bread improver (g) & 5 & 5 & 5 & 5 & 5 & 5 & 5 & 5 \\
Telur (g) & 30 & 30 & 30 & 30 & 30 & 30 & 30 & 0 \\
Xanthan gum (g) & 1.5 & 1.5 & 1.5 & 1.5 & 1.5 & 1.5 & 1.5 & 0 \\
\hline
\end{tabular}

\section{Metode}

Rancangan yang digunakan pada pelaksaan penelitian ini berupa rancangan acak lengkap non faktorial. Masing-masing perlakuan yang dibuat sebanyak 3 ulangan, sehingga total sampel menjadi 24 sampel. Jika diperoleh hasil berbeda nyata serta sangat nyata antara perlakuan, maka selanjutnya dilakukan uji lanjutan dengan uji Duncan.

\section{Prosedur Analisis}

Pengujian tekstur roti manis menggunakan LFRA Texture Analyzer. Menurut Rianti (2008), pengukuran ini menggunakan prinsip gaya tekan yang diberikan kebahan pada besaran tertentu maka tekstur bahan pangan berupa roti manis dapat diukur. Jenis probe yang digunakan tergantung dari bahan pangan yang diuji. Untuk roti manis, probe yang dipakai adalah jenis silinder yang memiliki ukuran diameter $28 \mathrm{~mm}$. Setelah probe dipasang, bahan yang akan diuji diletakkan di atas meja uji, kemudian komputer dinyalakan untuk menjalankan program texture analyzer expert. Hasil yang akan keluar berupa grafik dan dapat digunakan untuk pengolahan data lanjutan. Pengambilan contoh dilakukan secara acak. Grafik tersebut terdiri dari sumbu x yang merupakan waktu pengukuran (detik) dan sumbu y yang merupakan gaya (g). Data yang dihasilkan dari pengujian tekstur yaitu cohesiveness, chewiness, adhesiveness, \% deformasi, hardness, gumminess, dan springiness. Gambar 1 menunjukkan pengujian tekstur menggunakan LFRA Texture Analyzer.

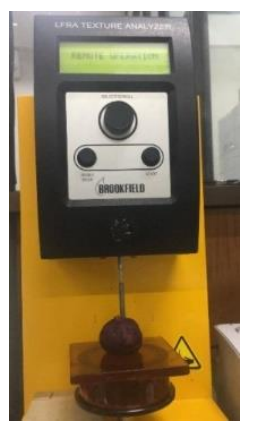

Gambar 1. Pengujian tekstur menggunakan LFRA Texture Analyzer 


\section{HASIL DAN PEMBAHASAN}

Tabel 2 merupakan hasil analisis tekstur roti manis dari tepung, pati, serat, dan pigmen antosianin ubi jalar ungu.

Tabel 2. Karakteristik tekstur pada roti manis

\begin{tabular}{|c|c|c|c|c|c|c|c|}
\hline $\begin{array}{l}\text { Perlak } \\
\text { uan }\end{array}$ & $\begin{array}{l}\text { Cohesi } \\
\text { veness }\end{array}$ & $\begin{array}{l}\text { Chewiness } \\
\text { (gmm) }\end{array}$ & $\begin{array}{c}\text { Adhesiveness } \\
\text { (gs) }\end{array}$ & $\begin{array}{c}\% \\
\text { deformasi } \\
(\%)\end{array}$ & $\begin{array}{l}\text { Hardness } \\
\text { (g) }\end{array}$ & $\begin{array}{c}\text { Gummin } \\
\text { ess }(\mathrm{g})\end{array}$ & $\begin{array}{l}\text { Springine } \\
\text { ss (mm) }\end{array}$ \\
\hline $\mathrm{P}_{1}$ & $\begin{array}{l}0.17 \pm \\
0.01^{c}\end{array}$ & $\begin{array}{l}2591.46 \pm \\
241.55^{\mathrm{b}, \mathrm{B}}\end{array}$ & $\begin{array}{c}-1133.39 \pm \\
69.37 \\
c, C D\end{array}$ & $\begin{array}{c}47.84 \pm \\
0.68 \\
b, B\end{array}$ & $\begin{array}{c}1000.0 \pm \\
53.74 \\
b, B\end{array}$ & $\begin{array}{c}222.5 \pm \\
21.42 \\
c, C\end{array}$ & $\begin{array}{c}9.50 \pm \\
0.26^{\mathrm{b}, \mathrm{B}}\end{array}$ \\
\hline $\mathrm{P}_{2}$ & $\begin{array}{l}0.22 \pm \\
0.01^{a}\end{array}$ & $\begin{array}{l}1140.54 \pm \\
120.20^{f, E}\end{array}$ & $\begin{array}{c}-1015.17 \pm \\
11.32 \\
b, B\end{array}$ & $\begin{array}{c}41.45 \pm \\
1.44 \\
\mathrm{e}, \mathrm{CD}\end{array}$ & $\begin{array}{c}641.25 \pm \\
17.32 \\
d, C\end{array}$ & $\begin{array}{c}107.5 \pm \\
3.87 \\
f, D\end{array}$ & $\begin{array}{c}11.8 \pm \\
0.17 \\
a, A\end{array}$ \\
\hline $\mathrm{P}_{3}$ & $\begin{array}{l}0.21 \pm \\
0.02^{\mathrm{ab}}\end{array}$ & $\begin{array}{c}1867.25 \pm \\
52.11^{\mathrm{e}, \mathrm{D}}\end{array}$ & $\begin{array}{c}-1024.73 \pm \\
2.78 \\
b, B\end{array}$ & $\begin{array}{c}41.82 \pm \\
0.14 \\
\mathrm{~cd}, \mathrm{CD}\end{array}$ & $\begin{array}{c}861.50 \pm \\
60.10 \\
c, B\end{array}$ & $\begin{array}{c}189.05 \pm \\
6.01 \\
e, C\end{array}$ & $\begin{array}{c}11.6 \pm \\
0.04 \\
a, A\end{array}$ \\
\hline $\mathrm{P}_{4}$ & $\begin{array}{l}0.21 \pm \\
0.02^{\mathrm{ab}}\end{array}$ & $\begin{array}{c}2041.48 \pm \\
104.44 \text { de,CD }\end{array}$ & $\begin{array}{c}-1057.46 \pm \\
15.78 \\
b, B C\end{array}$ & $\begin{array}{c}43.14 \pm \\
0.25 \\
d, C\end{array}$ & $\begin{array}{c}921.00 \pm \\
48.08 \\
\text { bc,B }\end{array}$ & $\begin{array}{c}192.43 \pm \\
11.57 \\
\text { de,C }\end{array}$ & $\begin{array}{c}10.2 \pm \\
0.81 \\
b, B\end{array}$ \\
\hline $\mathrm{P}_{5}$ & $\begin{array}{l}0.21 \pm \\
0.00^{\mathrm{a}}\end{array}$ & $\begin{array}{c}2252.11 \pm \\
191.71^{\mathrm{cd}, \mathrm{BCD}}\end{array}$ & $\begin{array}{c}-1063.57 \pm \\
5.48 \\
\mathrm{~b}, \mathrm{BC}\end{array}$ & $\begin{array}{c}45.91 \pm \\
0.13 \\
\mathrm{c}, \mathrm{B}\end{array}$ & $\begin{array}{c}945.25 \pm \\
51.27 \\
\text { bc,B }\end{array}$ & $\begin{array}{c}214.90 \pm \\
1.64 \\
\text { cd,C }\end{array}$ & $\begin{array}{c}10.1 \pm \\
0.61 \\
b, B\end{array}$ \\
\hline$P_{6}$ & $\begin{array}{l}0.19 \pm \\
0.00 \mathrm{abc}\end{array}$ & $\begin{array}{c}2463.66 \pm \\
103.03 \mathrm{bc}, \mathrm{BC}\end{array}$ & $\begin{array}{c}-1168.55 \pm \\
16.31 \\
c, D\end{array}$ & $\begin{array}{c}46.19 \pm \\
0.40 \\
\mathrm{c}, \mathrm{B}\end{array}$ & $\begin{array}{c}993.50 \pm \\
86.97 \\
b, B\end{array}$ & $\begin{array}{c}266.80 \pm \\
5.63 \\
b, B\end{array}$ & $\begin{array}{l}9.58 \pm \\
0.04^{\mathrm{b}, \mathrm{B}}\end{array}$ \\
\hline$P_{7}$ & $\begin{array}{l}0.17 \pm \\
0.00^{\mathrm{bc}}\end{array}$ & $\begin{array}{c}3823.18 \pm \\
66.33^{\mathrm{a}, A}\end{array}$ & $\begin{array}{c}-2412.65 \pm \\
0.09 \\
d, E\end{array}$ & $\begin{array}{c}50.95 \pm \\
0.27 \\
a, A\end{array}$ & $\begin{array}{c}1207.25 \pm \\
3.18 \\
a, A\end{array}$ & $\begin{array}{c}329.53 \pm \\
13.70 \\
a, A\end{array}$ & $\begin{array}{c}5.39 \pm \\
0.16 \\
c, C\end{array}$ \\
\hline $\mathrm{P}_{8}$ & $\begin{array}{l}0.23 \pm \\
0.02^{\mathrm{a}}\end{array}$ & $\begin{array}{l}260.57 \pm \\
23.67^{g, F}\end{array}$ & $\begin{array}{c}-480.12 \pm \\
26.54 \\
a, A\end{array}$ & $\begin{array}{c}40.20 \pm \\
1.00 \\
e, D\end{array}$ & $\begin{array}{c}330.25 \pm \\
7.42 \\
e, D\end{array}$ & $\begin{array}{c}53.09 \pm \\
5.30 \\
\mathrm{~g}, \mathrm{E}\end{array}$ & $\begin{array}{c}12.4 \pm \\
0,47 \\
a, A\end{array}$ \\
\hline
\end{tabular}

Keterangan : Data tektur roti manis terdiri dari 2 ulangan dan \pm menunjukkan standar deviasi. Angka yang diikuti dengan huruf yang berbeda pada baris yang sama menunjukkan pengaruh berbeda nyata pada taraf $5 \%$ (huruf kecil) dan berbeda sangat nyata pada taraf $1 \%$ (huruf besar) dengan uji LSR.

Adapun hasil roti manis dari tepung, pati, serat, dan pigmen antosianin ubi jalar ungu dapat dilihat pada Gambar 2.

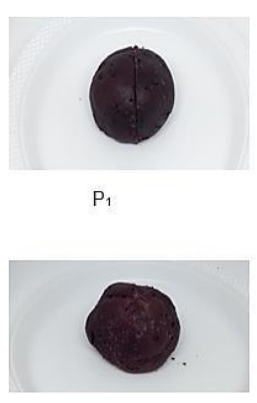

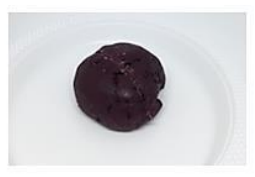

$\mathrm{P}_{2}$

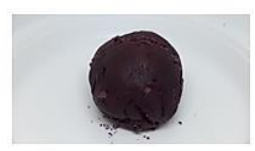

$P_{6}$

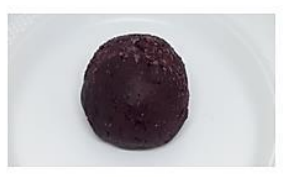

$\mathrm{P}_{3}$

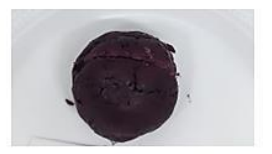

$P_{7}$

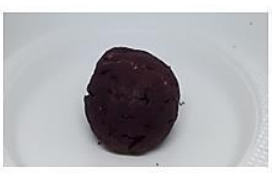

$\mathrm{P}_{4}$

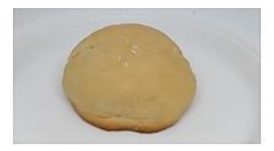

Keterangan: $P_{1}=100 \mathrm{~g}$ tepung ubi jalar ungu (kontrol 1), $P_{2}=73: 25: 0: 2, P_{3}:=73: 20: 5: 2, P_{4}=$ $73: 15: 10: 2, \mathrm{P}_{5}=73: 10: 15: 2, \mathrm{P}_{6}=73: 5: 20: 2, \mathrm{P}_{7}=73: 0: 25: 2, \mathrm{P}_{8}=100 \mathrm{~g}$ tepung terigu (kontrol 2)

Gambar 2. Hasil roti manis dari tepung, pati, serat, dan pigmen antosianin ubi jalar ungu 


\section{Cohesiveness}

Cohesiveness adalah area tekan dari kompresi kedua hingga kompresi pertama. Cohesiveness merupakan tingkatan bahan saat dapat dihancurkan oleh gerakan mekanis (Indiarto, dkk., 2012). Perbandingan tepung, pati, serat, dan pigmen antosianin ubi jalar ungu menenunjukkan adanya pengaruh berbeda nyata atau $P$ lebih kecil dari 0.05 untuk cohesiveness roti manis. Roti manis $\mathrm{P}_{8}$ memiliki cohesiveness tertinggi yaitu 0.23 sedangkan $\mathrm{P}_{1}$ dan $\mathrm{P}_{7}$ memiliki cohesiveness terendah yaitu 0.17 .

Shaliha, dkk., (2017), menyebutkan bahwa apabila cohesiveness (keutuhan) semakin tinggi maka keutuhan atau kekompakan bahan semakin tinggi. Roti manis $\mathrm{P}_{8}$ (kontrol 2) yang memiliki cohesiveness tertinggi, sehingga memiliki keutuhan dan kekompakan bahan tertinggi karena roti manis $P_{8}$ terbuat dari $100 \%$ tepung terigu. Igoe dan Hui (1986), menyatakan bahwa pada saat adonan yang mengandung gluten dipanaskan maka akan membentuk produk yang padu (cohesive). Menurut Damoran dan Paraf (1997), protein yang terdapat pada tepung terigu dapat membuat jaringan-jaringan yang berikatan sehingga lebih kompak.

Selain itu, penambahan pati yang semakin banyak pada roti manis $P_{2}$ (73:25:0:2) juga dapat meningkatkan cohesiveness karena pati ubi jalar ungu mempunyai amilopektin yang lebih tinggi jika dibandingkan dengan amilosanya. Tjkrodikosoemo (1986), menyatakan sifat dari amilopektin yaitu daya rekat tinggi, sehingga dapat menyebabkan semakin meningkat kekompakan dari suatu produk. Sebaliknya, roti manis $P_{7}$ (73:0:25:2) memiliki cohesiveness yang rendah karena pada roti manis $\mathrm{P}_{7}$ tidak diberikan tambahan pati. Hasil penelitian Muthoharoh dan Sutrisno (2017), yaitu formulasi dari roti bebas gluten harus membutuhkan bahan yang dapat berfungsi sebagai pengganti gluten dalam gas $\mathrm{CO}_{2}$ sehingga gas dapat terperangkap dalam adonan. Thibodeau (2009), menyatakan bahwa roti bebas gluten tidak memiliki daya kohesi yang baik karena tidak adanya gluten sehingga menyebabkan tekturnya keras dan akan hancur saat penekanan awal.

\section{Chewiness}

Chewiness merupakan energi yang dibutuhkan untuk mengunyah makanan dan biasanya digunakan pada makanan semi padat. Secara sederhana chewiness berarti daya kunyah (Chandra dan Shamasundar, 2015). Perbandingan tepung, pati, serat, dan pigmen antosianin ubi jalar ungu menunjukkan adanya pengaruh berbeda sangat nyata atau $\mathrm{P}$ lebih kecil dari 0.01 untuk chewiness roti manis. Roti manis $\mathrm{P}_{7}$ (73:0:25:2) memiliki chewiness tertinggi yaitu $3823.18 \mathrm{gmm}$. Menurut Chandra dan Shamasundar (2015) chewiness erat kaitannya dengan parameter hardness, cohesiveness, dan springiness. Hal ini dapat dibuktikan dengan melihat Tabel 2. Pada Tabel 2 dapat dilihat roti manis $P_{7}$ memiliki hardness tertinggi, cohesiveness terendah, dan springiness terendah sehingga dengan penambahan serat semakin banyak dapat menyebabkan chewiness semakin tinggi.

Roti manis $P_{8}$ (kontrol 2) memiliki chewiness yang terendah yaitu 260,57 gmm karena roti manis $\mathrm{P}_{8}$ memiliki hardness yang terendah, cohesiveness yang tertinggi, dan springiness yang tertinggi. Adanya penggunaan gluten mempengaruhi nilai dari parameterparameter tersebut. Menurut Kristalia (2018), chewiness berkaitan dengan kekuatan elastisitas matriks protein. Damodaran dan Paraf (1997), menyatakan bahwa gluten memiliki kemampuan untuk membentuk suatu jaringan yang saling berikatan sehingga menjadi kompak dan elastis.

Roti manis $\mathrm{P}_{2}$ (73:25:0:2) memiliki chewiness yang terendah kedua setelah roti manis $P_{8}$. Penambahan pati yang semakin banyak mempengaruhi hardness menjadi semakin rendah, cohesiveness semakin tinggi, dan springiness semakin rendah. Ginting dan Suprapto (2005), menyatakan bahwa meskipun pati ubi jalar tidak memiliki kandungan gluten tapi tetap memiliki sifat yang elastis karena kemampuannya untuk menyerap air serta sifat membentuk gel (gelatinisasi). Sedangkan dengan adanya tambahan serat maka sifatsifat fungsional dari pati juga semakin berkurang sehingga dapat berpengaruh terhadap 
mutu tesktur produk. Irhami dkk., 2019 menyatakan bahwa kandungan pati lebih tinggi terdapat dari pati yang telah terekstraksi daripada rendemen serat yang dihasilkan.

\section{Adhesiveness}

Adhesiveness dapat disebut sebagai gaya yang diperlukan untuk dapat menarik makanan dari permukannya (Haliza dkk., 2012). Perbandingan tepung, pati, serat, dan pigmen antosianin ubi jalar ungu menunjukkan adanya pengaruh berbeda sangat nyata atau $\mathrm{P}$ lebih kecil dari 0.01 untuk adhesiveness roti manis. Roti manis $\mathrm{P}_{8}$ (kontrol 2) memiliki adhesiveness tertinggi yaitu $-480.12 \mathrm{gmm}$ dan yang terendah yaitu roti manis $\mathrm{P}_{7}$ (73:0:25:2) yaitu -2412.65 gmm. Menurut Haliza dkk., (2012), adhesiveness didapat dari kurva yang berada dibawah garis dan nilainya biasanya memiliki nilai yang negatif, semakin tinggi nilai (mendekati positif) maka nilai adhesiveness yang terukur juga semakin tinggi.

Menurut Shaliha dkk., (2017), semakin tinggi adhesiveness maka semakin tinggi daya lengket dari bahan. Roti manis $\mathrm{P}_{8}$ memiliki daya lengket yang tertinggi karena memiliki adhesiveness yang tertinggi. Menurut Igoe dan Hui (1986), pemanasan adonan yang mengandung gluten dapat menyebabkan terbentuknya sifat lengket (adhesive) Nilai adhesiveness yang tinggi berbanding lurus dengan sifat lengket yang semakin tinggi Kuswardani dkk., (2008), juga menyatakan ketika tepung terigu bercampur dengan air akan menyebabkan terbentuknya polimer-polimer yang membentuk lapisan film sehingga produk menjadi lengket.

Roti manis $\mathrm{P}_{2}$ (73:25:0:2) memiliki tingkat adhesiveness yang tertinggi setelah roti manis $\mathrm{P}_{8}$ karena roti manis $\mathrm{P}_{2}$ dilakukan penambahan pati. Menurut Tjokrodikosoemo (1968), amilopektin yang terkandung pada pati dapat meningkatkan sifat daya rekatnya sehingga juga mempengaruhi sifat kelengketannya. Sebaliknya, pada roti manis $\mathrm{P}_{7}$ (73:0:25:2) memiliki adhesiveness yang rendah karena pada perlakuan ini tidak adanya penambahan pati.

\section{4. \% deformasi}

$\%$ deformasi merupakan persentase dari jumlah pressing pada produk sehingga dapat berubah bentuk ketika diberikan gaya tekan (Asmoro dkk., 2017). Perbandingan tepung, pati, serat, dan pigmen antosianin ubi jalar ungu menunjukkan adanya pengaruh berbeda sangat nyata atau $\mathrm{P}$ lebih kecil dari 0.01 untuk \% deformasi roti manis. Roti manis $\mathrm{P}_{7}$ (73:0:25:2) memiliki \% deformasi tertinggi yaitu 50.95\% dan roti manis $\mathrm{P}_{8}$ (kontrol 2) memiliki terendah yaitu $40.20 \%$.

Roti manis $\mathrm{P}_{7}$ memiliki perubahan bentuk yang lebih tinggi setelah dikenakan gaya karena memiliki \% deformasi yang paling tinggi. Roti manis $\mathrm{P}_{1}$ juga memiliki perubahan bentuk yang cukup tinggi. Hal ini terjadi karena roti manis $P_{7}$ terbuat dari $75 \mathrm{~g}$ tepung ubi jalar ungu dan $25 \mathrm{~g}$ serat serta $P_{1}$ terbuat dari $100 \mathrm{~g}$ tepung ubi jalar ungu. Penggunaan serat dapat meningkatkan sifat perubahan bentuk menjadi lebih tinggi. Menurut Wasseman (1979), bahwa sifat reologi tergantung terhadap gas yang dapat terperangkap dalam produk. Peningkatan substitusi tepung atau bahan yang rendah gluten dapat menyebabkan gas $\mathrm{CO}_{2}$ hasil fermentasi yang dapat terperangkap menurun. Semakin rendah gas $\mathrm{CO}_{2}$ yang terperangkap dalam produk maka dapat meningkatkan deformasi (perubahan bentuk) suatu bahan.

Roti manis $\mathrm{P}_{8}$ memiliki \% deformasi yang terendah Keberadaan gluten dapat memerangkap gas $\mathrm{CO}_{2}$ sehingga \% deformasinya menjadi rendah. Muthoharoh dan Sutrisno (2017), menyatakan bahwa gluten dapat mempertahankan gas $\mathrm{CO}_{2}$ hasil fermentasi sehingga terperangkap dalam adonan. Penambahan pati dengan proporsi $25 \mathrm{~g}$ dan serat $0 \mathrm{~g}$ pada roti manis $\mathrm{P}_{2}$ memberikan pengaruh terhadap \% deformasinya sehingga mendekati \% deformasi $P_{8}$. Hal ini dapat disebabkan oleh penggunaan pati yang dapat membantu pengembangan roti. Penelitian Ginting dan Suprapto (2005), menyebutkan bahwa meskipun pati ubi jalar tidak memiliki gluten, namun memiliki sifat menarik air dan membengkak serta memiliki sifat terbentuknya gel yang konsisten pada saat pemanggangan sehingga roti dapat mengembang dengan baik. 


\section{Hardness}

Hardness digunakan untuk mendeskripsikan ketidakhalusan remah dari produk. Semakin tinggi hardness maka produk cenderung semakin keras (Haliza dkk., 2012). Perbandingan tepung, pati, serat, dan pigmen antosianin ubi jalar ungu menunjukkan adanya pengaruh berbeda sangat nyata atau $\mathrm{P}$ lebih kecil dari 0.01 untuk hardness roti manis. Roti manis $\mathrm{P}_{7}$ (73:0:25:2) memiliki hardness tertinggi yaitu $1207.25 \mathrm{~g}$. Roti manis $\mathrm{P}_{1}$ juga memiliki hardness yang cukup tinggi yaitu $1000.0 \mathrm{~g}$. Penggunaan tambahan serat sebanyak 25 g pada $P_{7}$ dapat meningkatkan hardness roti manis dibandingkan dengan $P_{1}$ yang hanya menggunakan $100 \mathrm{~g}$ tepung ubi jalar ungu. Menurut Indiarto dkk., (2012), hardness adalah nilai maksimum dari gigitan pertama atau gaya tekan pertama. Satuan yang dipakai untuk hardness adalah $\mathrm{N}$, kg, dan $\mathrm{g}$. Roti manis $\mathrm{P}_{8}$ (kontrol 2) memiliki hardness yang terendah karena terbuat dari $100 \%$ tepung terigu. Muthoharoh dan Sutrisno (2017), menyatakan bahwa adanya gluten pada adonan dapat berfungsi untuk memerangkap gas sehingga menyebabkan produk menjadi mengembang.

Roti manis $\mathrm{P}_{2}$ (73:25:0:2) memiliki hardness terendah kedua setelah roti manis $\mathrm{P}_{8}$ karena roti manis $P_{2}$ menggunakan penambahan pati sehingga dapat menyebabkan pengembangan yang baik pada roti. Penelitian Ginting dan Suprapto (2005), menyebutkan bahwa meskipun pati ubi jalar tidak memiliki gluten, namun memiliki sifat menarik air dan membengkak serta memiliki sifat terbentuknya gel yang konsisten pada saat pemanggangan sehingga roti dapat mengembang.

\section{Gumminess}

Gumminess merupakan energi yang digunakan untuk mengecilkan bahan makanan sehingga dapat ditelan (Szczesniak, 2002). Perbandingan tepung, pati, serat, dan pigmen antosianin ubi jalar ungu menunjukkan adanya pengaruh berbeda sangat nyata atau $\mathrm{P}$ lebih kecil dari 0.01 untuk gumminess roti manis. Roti manis $\mathrm{P}_{8}$ (kontrol 2) memiliki gumminess terendah yaitu $53.09 \mathrm{~g}$. Menurut Indiarto dkk., (2012), gumminess merupakan karakteristik dari bahan pangan semipadat dengan hardness rendah dan cohesiveness yang tinggi. Pada Tabel 2 dapat dilihat roti manis $\mathrm{P}_{8}$ memiliki hardness rendah dan cohesiveness tertinggi. Semakin rendah hardness dan semakin tinggi cohesiveness maka gumminessnya semakin rendah. Rendahnya hardness dapat dikaitkan dengan adanya penggunaan gluten pada roti manis $\mathrm{P}_{8}$. Muthoharoh dan Sutrisno (2017), menyatakan bahwa adanya gluten pada adonan dapat berfungsi untuk memerangkap gas sehingga menyebabkan produk menjadi mengembang. Selain itu, penggunaan tepung terigu menyebabkan kekompakan semakin tinggi. Damodaran dan Paraf (1997), menyatakan bahwa gluten memiliki kemampuan untuk membentuk suatu jaringan yang saling berikatan sehingga menjadi kompak dan elastis.

Roti manis $\mathrm{P}_{2}$ memiliki gumminess yang cukup rendah yaitu $107.50 \mathrm{~g}$ serta hardness yang cukup rendah dan cohesiveness yang cukup tinggi. Hal ini disebabkan karena roti manis $P_{2}$ mengandung tambahan pati terbanyak yaitu $25 \mathrm{~g}$. Suprapto (2005), menyatakan bahwa meskipun pati ubi jalar tidak memiliki kandungan gluten tapi tetap memiliki sifat yang elastis karena kemampuannya untuk menyerap air serta sifat membentuk gel (gelatinisasi).

\section{Springiness}

Springiness atau elastisitas merupakan waktu pemulihan antara waktu gigitan pertama dengan gigitan kedua (Indiarto dkk., 2012). Perbandingan tepung, pati, serat, dan pigmen antosianin ubi jalar ungu menunjukkan adanya pengaruh berbeda sangat nyata atau $P$ lebih kecil dari 0.01 untuk springiness roti manis. Roti manis $P_{8}$ (kontrol 2) memiliki springiness tertinggi yaitu $12.44 \mathrm{~g}$. Haliza dkk., (2012), menyatakan springiness adalah tinggi diantara gigitan pertama dan kedua yang dapat dicapai oleh makanan.

Roti manis $\mathrm{P}_{8}$ memiliki waktu untuk kembali ke posisi awal setelah dikompresi pertama yang tertinggi jika dibandingkan roti yang lain. Damodaran dan Paraf (1997), menyatakan protein yang terdapat pada terigu dapat membuat jaringan-jaringan yang berikatan (continuous) pada adonan sehingga dapat membentuk adonan yang elastis. 
Roti manis $\mathrm{P}_{2}$ (73:25:0:2) memiliki springiness tertinggi kedua setelah roti manis $\mathrm{P}_{8}$. Hal ini dapat disebabkan pada roti manis $\mathrm{P}_{2}$ dilakukan penambahan pati yang semakin banyak. Ginting dan Suprapto (2005), menyatakan bahwa meskipun pati ubi jalar tidak memiliki kandungan gluten, namun tetap memiliki sifat yang elastis karena kemampuannya untuk menyerap air serta sifat membentuk gel (gelatinisasi). Hal ini juga dijelaskan dalam penelitian Haliza dkk., (2012), walaupun dalam pembuatan brownies menggunakan tepung non terigu tetap akan terbentuk protein-pati-lipid. Protein dan pati memiliki peran untuk dapat membentuk struktur dari adonan dengan memerangkap udara pada matriks pati-proteinlipid.

\section{SIMPULAN}

Perbandingan tepung, pati, serat, dan pigmen antosianin ubi jalar ungu menunjukkan pengaruh berbeda nyang yata $(P<0.05)$ untuk cohesiveness serta berbeda yang sangat nyata $(\mathrm{P}<0.01)$ untuk chewiness, adhesiveness, \% deformasi, hardness, gumminess, dan springiness.

Penambahan pati ubi jalar ungu dengan jumlah semakin meningkat pada roti manis dapat meningkatkan cohesiveness, adhesiveness, springiness, dan gumminess serta menurunkan \% deformasi sedangkan penambahan serat ubi jalar ungu dengan jumlah semakin meningkat pada roti manis dapat meningkatkan chewiness, hardness, dan gumminess.

Formulasi $\mathrm{P}_{2}$ (73:25:0:2) merupakan formulasi roti manis yang memiliki karakteristik tekstur mendekati roti manis yang terbuat dari tepung terigu $\left(\mathrm{P}_{8}\right)$. Hal tersebut disebabkan adanya penambahan pati terbanyak sehingga memiliki sifat elastis seperti gluten pada tepung terigu.

\section{UCAPAN TERIMAKASIH}

Kami mengucapkan terimakasih kepada Direktorat Jenderal Penguatan dan Pengembangan Riset, Kementerian Riset, Teknologi dan Pendidikan Republik Indonesia atas pendanaan penelitian ini melalui proyek "Penelitian Terapan 2019".

\section{DAFTAR PUSTAKA}

Andragogi, V., V.P. Bintoro, dan Susanti. S. 2018. Pengaruh berbagai jenis gula terhadap sifat sensori dan nilai gizi roti manis. Jurnal Teknologi Pangan. 2:2, 163-167

Asmoro, N. W., Hartati, S. dan Handayani, C.B. 2017. Karakteristik fisik dan organoleptik produk mocatilla chips dari tepung mocaf dan jagung. Jurnal IImu Pangan dan Hasil Pertanian. 1:1, 63-70

Barlina, R. 2013. Substitusi pati sagu pada pengolahan roti manis. B. Palma. $14: 2,117-134$

Chandra, M. V. and Shamasundar, B. A. 2015. Texture profile analysis and functional properties of gelatin from the skin of three species of fresh water fish. International Journal of Food Properties. 18:1, 572-58

Chuango, K. 2018. Pengaruh perlakuan awal (pre-treatment) dalam pembuatan tepung ubi jalar ungu terhadap mutu cakes. Skripsi. USU. Medan

Damoran, S. and Paraf, A. 1997. Food Protein and Their Applications. Marcel Dekker. New York

Fatmala, I. A. dan Adi, A. C. 2017. Daya terima dan kandungan protein biskuit substitusi tepung ubi jalar ungu dan isolat protein kedelai untuk pemberian makanan tambahan ibu hamil kek. Media Gizi Indonesia. 12:2, 156-163

Ginting, E. dan Suprapto. 2005. Pemanfaatan pati ubi jalar sebagai substitusi terigu pada pembuatan roti manis. Prosiding Seminar Nasional Teknologi Inovatif Pasca Panen 
untuk Pengembangan Industri Berbasis Pertanian, Balai Besar Penelitian dan Pengembangan Pasca Panen Pertanian, Bogor, 86-97

Halim, A., Ali, dan Rahmayani, 2015. Evaluasi mutu roti manis dari tepung komposit (tepung terigu, pati sagu, tepung tempe). Jurnal Teknologi dan Industri Pertanian. 7:2, 1-5

Haliza, W., Kailaku, S. I. Dan Yuliani, S. 2012. Penggunaan mixture response surface methodology pada optimasi formula brownies berbasis tepung talas banten (Xanthosoma undipes K. Koch) sebagai alternatif pangan sumber serat. J. Pascapanen. 9:2, 96-100

Hardoko, L. Hendarto, dan Siregar, T. M. 2010. Pemanfaatan ubi jalar ungu (Ipomoea batatas L. Poir) sebagai pengganti sebagian tepung terigu dan sumber antioksidan pada roti tawar. J. Teknol. dan Industri Pangan. 21:1, 25-32

Igoe, R, S., and Yui, Y.H. 1986. Dictionary of Food Ingredients, $3^{\text {rd }}$ Edition. Chapman \& Hall. New York

Indiarto, R. B., Nurhadi, dan Subroto, E. 2012. Kajian karakteristik tesktur (texture profil analysis) dan organoleptik daging ayam asap berbasisi teknologi asap cair tempurung kelapa. Jurnal Teknologi Hasil Pertanian. 5:2, 106-116

Irhami, C. Anwar, dan Kemalawaty, M. 2019. Karakteristik sifat fisikokimia pati ubi jalar dengan mengkaji jenis varietas dan suhu pengeringan. Jurnal Teknologi Pertanian. $20: 1,33-44$

Kristalia, K. K. 2018. Analisis kimia kualitas produk akhir pasta di PT. Indofood Sukses Makmur Tbk.-Bogasari Division Jakarta. Laporan Kerja Praktek. Fakultas Teknologi Pertanian. Universitas Katolik Soegijapranata, Semarang. http://repository.unika.ac.id/18428/. Tanggal akses: 18/072019

Kuswardani, I., C. Y. Trisnawati, dan Faustine. 2008. Kajian penggunaan xanthan gum pada roti tawar non gluten yang terbuat dari maizena, tepung beras, dan tapioka. Jurnal Teknologi Pangan dan Gizi. 7:1, 55-65

Muthoharoh, D. dan Sutrisno, A. 2017. Pembuatan roti tawar bebas gluten berbahan baku tepung, garut, tepung beras, dan maizena (konsentrasi glukomanan dan waktu proofing). Jurnal Pangan dan Agroindustri. 5:2, 34-44

Rianti, A. W. 2008. Kajian formulasi cookies ubi jalar (Ipomoea batatas L.) dengan karakteristik tekstur menyerupai cookies keladi. Skripsi. IPB. Bogor

Santosa, I., Winata, A. P., dan Sulistiawati, E. 2016. Kajian sifat kimia dan uji sensori tepung ubi jalar putih hasil pengeringan cara sangrai. Chemica. 3:2, 55-60

Shaliha, L. A., Abduh, S. B. M., Hintono, A. 2017. Aktivitas antioksidan, tekstur, dan kecerahan ubi jalar ungu (Ipomoea batatas) yang dikukus pada berbagai lama waktu pemanasan. Jurnal Aplikasi Teknologi Pangan. 6:4, 141-160

Sigit, B., Atmaka, W., dan Apriliyanti, T. 2005. Kajian sifat fisikokimia dan sensori tepung ubi jalar ungu (Ipomoea batatas blackie) dengan variasi proses pengeringan. Jurnal Pertanian Universitas Sebelas Maret. 1:1, 788-793

Silalahi, J. 2006. Makanan Fungsional. Kanisius. Jakarta.

Szczesniak, A. S. 2002. Texture is a sensory property. J Food Quality and Preference. 13:2, 215-225

Tjokrodikoesomo, P. S. 1986. HFS dan Industri Ubi Kayu Lainnya. PT Gramedia. Jakarta

Waramboi, J. G., Dennien, S., Gidley, J. M., and Sopade, A. P. 2011. Characterization of sweetpotato from Papua New Guinea and Australia: Physicochemical, pasting and gelatinization properties. Food Chemistry. 126:1, 1759-1770

Wasseman, L. 1979. Relationship between Structure and Rheology Properties of Bread Crumb. Academic Press. London

Wegener, C. B., Jansen, G., Jurgensa, H., and Schutzeb, W. 2009. Special quality traits of coloured potato breeding clones: Anthocyanins, soluble phenols and antioxidant capacity. J. Sci. Food Agri. 89:1, 206-215

Woolfe, J. A. 1999. Sweet potato : an Untapped Food Resources. Chapman and Hall. . New York 